\title{
Feckless Fathers, Fraught Families: Abandonment and Cultural Change in the Early Modern Jewish World
}

\author{
Jessica Vance Roitman
}

For all intents and purposes, it would seem that Selomoh Gomes Soares made a modest success of his nearly four decades in Suriname, the Dutch plantation colony clinging to the edge of the South American mainland. By the time he died in 1805 , he had worked for ten years as the Jewish community's doctor, surgeon, and apothecary to the poor. ${ }^{1}$ He owned a small plot of land, and was at least somewhat active in the life of the community. For instance, he was a member of the choir (adjudante do corro) in the jubilee celebration marking the one hundredth anniversary of Congregation Beraha VeSalom. ${ }^{2}$ Yet had Soares immigrated to America in the early years of the twentieth century instead of Suriname in the mid-eighteenth, he very well might have shown up in "A Gallery of Vanished Husbands." This was a feature that appeared several times a week for decades in the New York-based Yiddish newspaper Der Forverts. This section of the paper exhibited portraits of husbands who had deserted their families, along with abbreviated descriptions of the deserters' circumstances and identifying characteristics in the hopes that they could be found. ${ }^{3}$ You see, Gomes Soares had left his wife, Simha Salom, and at least

1 National Archive of the Netherlands, The Hague (hereafter NL-HaNA), Suriname: Nederlands Portugees-Israëlitische Gemeente (Portugees-Israëlitische Gemeente Suriname), 1.05.11.18, inventory number (hereafter inv. nr.) 3, 29 December 1795. I am grateful to Dr. Aviva Ben-Ur for so generously sharing with me the fruits of her labors in the archives of the Portuguese Jewish community of Suriname. Parts of this chapter have appeared previously in Aviva BenUr and Jessica Vance Roitman, "Adultery Here and There: Crossing Sexual Boundaries in the Dutch Jewish Atlantic," in Dutch Atlantic Connections, 1680-180o: Linking Empires, Bridging Borders, eds. Gert Oostindie and Jessica Vance Roitman (Leiden: Brill, 2014), 216-23.

2 NL-HaNA, Portugees-Israëlitische Gemeente Suriname, 1.05.11.18, inv. nr. 2, 8 September 1785, p. 305 .

3 Bluma Goldstein, Enforced Marginality: Jewish Narratives on Abandoned Wives (Berkeley: University of California Press, 2007), 92.

(C) JESSICA VANCE ROITMAN, 2019 | DOI:10.1163/9789004392489_023

This is an open access chapter distributed under the terms of the prevailing CC-BY-NC License at the time of publication. 
two children behind in Amsterdam while he sought his fortune in the "New World." 4

There has been a compelling myth of the Jewish family as a fundamentally strong and stable institution. This "romantically idealized image of the Jewish family as warm, supportive, and ever-nurturing" has, according to historian Paula E. Hyman, a long history: "In the past two centuries," she writes, "Jewish communal leaders have been quick to celebrate the virtues of Jewish family life for purposes of self-gratification as well as apologetics, but they have been equally quick, in periods of rapid social change, to blame contemporary Jewish families for failing to live up to the standards of a noble past.".5 Indeed, historians of Jewish life have too often overlooked the serious dislocations that Jewish families experienced while privileging an image of Jewish familial solidity. Such a focus is somewhat puzzling because the archives of Jewish communities worldwide are filled with records documenting the large numbers of divorces, adulterous unions, children born out of legally sanctioned wedlock, and abandoned women such as Simha Salom.

In fact, there was no "noble past" for Jewish families, and the early twentieth century "Gallery of Vanished Husbands" was only the most visible manifestation of a phenomenon that had been going on for millennia-spousal abandonment-with poverty, adultery, and illegitimacy as some of its consequences. Gomes Soares was, for instance, hardly the only man to desert his family during the early modern period, and the situation his wife and children found themselves in was all-too-common in early modern Jewish communities. As this chapter will illustrate, the disruptions of early modernity, including demographic shifts, migration, European expansion overseas, the

4 Three births were registered to Selomoh Gomes Soares and Simha Salom: Ester, in 1763, Rachel, in 1764, and Jeudit, in 1766. Amsterdam Municipal Archive (Stadsarchief Amsterdam, hereafter SAA) Portugees-Israëlietische Gemeente, 334, inv. nr. 345 (Geboorteregister [Birth registry]), 108, 112, 120. We must assume that Rachel died at some point before or during the events which transpired, as she disappears from the historical record, though we have found no record of her death. The case of Simha Salom has previously been discussed in Ben-Ur and Jessica Roitman, "Adultery Here and There," in Oostindie and Roitman, Dutch Atlantic Connections and in Yosef Kaplan, "Moral Panic in the 18th-Century Sephardic Community of Amsterdam: The Threat of Eros," in Dutch Jewry. Its History and Secular Culture (1500-2000), ed. Jonathan Israel and Reinier Salverda (Leiden: Brill, 2002), 106-7.

5 Paula E. Hyman, "Introduction: Perspectives on the Evolving Jewish Family," in The Jewish Family: Myths and Reality, ed. Steven M. Cohen and Paula E. Hyman (New York: Holmes and Meier, 1986), 3-4. See also Morris D. Waldman, "Family Desertion," in Proceedings of the Sixth Biennial Session of the National Conference of Jewish Charities in the United States (St. Louis, May 17-19, 1910), 62: "The large proportion of such cases [desertion] among Jews is alarming in the light of our pride in the decency and purity of the Jewish family life." 
beginnings of industrialization, the Enlightenment and haskalah, and the emergence of greater acceptance for Jews in Christian society greatly affected the structure, size, character, economy, customs, and commitments of Jewish families, Ashkenazim and Sephardim alike, and exacerbated the always present problem of abandoned women and children. This problem was in no way isolated to Jewish communities, however, and the chapter will situate the issue within the larger context of early modernity, generally, and the Dutch Republic and its overseas colonies, specifically.

Despite the (self-) image of the Portuguese Jews of Amsterdam as aristocratic and wealthy, more than forty percent of the population was impoverished. ${ }^{6}$ The Sephardic economist and political philosopher, Isaac de Pinto, wrote of this problem of poverty in his Reflexoes Politicas in 1748. In it, he proposed sending impoverished Jews to Suriname. ${ }^{7}$ And, in fact, between 1759 and 1814, 430 so-called despachados (literally, "those who are despatched or sent away") left Amsterdam, a third going to Suriname and the others going as far afield as the Balkans, England, and to various points throughout the Americas. Only nineteen percent of those arriving in Suriname came with their spouses or families. The rest arrived alone, some after leaving a family in their city of origin. ${ }^{8}$

While there is no evidence that Selomoh Gomes Soares was one of these despachados, he certainly had left his family behind to seek his fortune. ${ }^{9} \mathrm{He}$

6 Tirtsah Levie Bernfeld, "Financing Poor Relief in the Spanish-Portuguese Jewish Community in Amsterdam in the Seventeenth and Eighteenth Centuries," in Israel and Salverda, Dutch Jewry, 101.

7 Isaac de Pinto, Reflexoens Politicas, Tocante à Constituiçám da Naçam Judaica, Exposiçam do estado de suas Finanças, causas dos atrasos, e desordens que se experimentam, e meyos de os prevenir (Amsterdam, 1748). On the problem of poverty in the Sephardic Jewish community, in general, see the excellent work of Tirtsah Levie Bernfeld, Poverty and Welfare Among the Portuguese Jews in Early Modern Amsterdam (Liverpool: Littman Library of Jewish Civilization and Liverpool University Press, 2012) and her "Financing Poor Relief," 63-102.

8 Robert Cohen, Jews in Another Environment. Surinam in the Second Half of the Eighteenth Century (Leiden: Brill, 1991), 25. Suriname was the primary destination for these Jews. Cohen's calculations show that 135 poor Jews were sent to Suriname between $1759^{-1814}$, more than to any other single destination.

9 I was not able to find a reference to Gomes Soares in the records of the despachados held in the Portuguese Jewish community of Amsterdam's archives SAA 344, inv. nr. 978, 17591802 (Registro dos despachos [Register of those dispatched]) or in SAA 344, inv. nr. 970-97, 1735-176o, 1772-1792 (Register van uitkeringen aan lidmaten als reisgeld om naar elders te vertrekken). 
may not have been poor enough to qualify as a despachado, but he was also not among the wealthy members of the community. ${ }^{10}$ His reasons for leaving his family behind to go to Suriname may have been financial, though there could also have been some other personal reasons that compelled him to set sail for the tropics. In any case, he must have been away from Amsterdam by 1767 , as the events that are described below show, though the earliest known official record of Soares's presence in Suriname is 1772 , so he could have gone elsewhere first. ${ }^{11}$ Be that as it may, in 1768 , his wife, Simha Salom, was publically accused of adultery by the parnassim of the Portuguese Jewish community in Amsterdam. It was a forceful accusation. She was pregnant, and her husband was known to have been away long enough for the community to calculate that the unborn child could not be his.

Two anonymous witnesses came forward to identify David, the son of Daniel de León, as the father of the fetus. The parnassim coyly refrained from naming the accusers in the communal minutes, writing only that "two people who have asked the President to remain anonymous" have come forward..$^{12}$ These same two unnamed men or women further asserted that David had rented Simha a house in which she could remain concealed for the duration of her pregnancy. But his efforts were to no avail. This is not overly surprising. The Portuguese Jewish community in Amsterdam was not large, equaling around three thousand people, and word traveled quickly.13 Gossip and the informal transfer of information to reinforce community norms were of vital importance within this and, indeed, most early modern (Jewish) communities. ${ }^{14}$

As soon as news of the pregnancy reached the parnassim's ears, they acted quickly to assert control over their wayward members and demand conformity to their rules. Simha and David were called before the august body because it had "come to their knowledge" that they had committed a "great crime against

10 SAA 344 (Register van administratie van de finta [Register of the administration of the obligatory community contribution or tax]), $285^{-287}$.

11 NL-HaNA, Portugees-Isrälitische Gemeente Suriname, 1.05.11.18, inv. nr. 135, p. 67. He received a piece of land valued at two hundred Dutch guilders from Jacob de Abraham de Meza.

12 SAA 334, inv. nr. 22 (Compendio de escamoth [Regulations], 1728-1814), 265. All discussion of this case is based on this file, unless otherwise cited.

13 Hubert Ph. H. Nusteling, "The Jews in the Republic of the United Provinces: Origin, Numbers and Dispersion," in Israel and Salverda, Dutch Jewry, 58.

14 On the importance of informal knowledge transfer and gossip within Portuguese Jewish communities, see Jessica Vance Roitman, "The Repercussions of Rumor: An Adultery Case from 18th-Century Curaçao," in A Sefardic Pepper-Pot in the Caribbean, ed. Michael Studemund-Halévy (Barcelona: Tirocinio, 2016), 124-35. 
our law."15 David de León initially refused to appear in the synagogue to answer the charges against him. In fact, de León managed to avoid coming before the parnassim by absenting himself from the city. For over three weeks, no one knew where to find him. His father, when questioned, claimed not to have seen him and to have no idea where he might be. The regents then instigated a search of the city to locate him. It is not clear if their search was successful, or whether de León finally decided to come forward of his own volition. ${ }^{16}$

In the meantime, Simha did come before the parnassim. According to her testimony to the Mahamad, she was seduced by the young man who slept with her on occasion in his father's home. She confirmed the account of the two anonymous witnesses, and stated that when her pregnancy became known to David, he rented a special house for her to conceal her condition from the public. Simha already had at least two daughters, Ester and Jeudit, and her daughter Rachel may have still been alive at this point, which likely made concealment even harder to accomplish. ${ }^{17}$ Once de León finally appeared in the synagogue, he broke down and confessed his adulterous affair with Simha Salom. On 5 July 1768 (20 Tamuz 5528), David, son of Daniel de León, and Simha Salom, wife of Solomon Gomes Soares, were excommunicated in the Portuguese Synagogue of Amsterdam.

This excommunication was brief. The usual punishments that accompanied such a sentence, including not being allowed to communicate with anyone outside of their immediate families, applied. De León was expected to participate in a very public and highly ritualized act in order to be reconciled with the community. He was required to climb the stairs on the left side of the pulpit within the synagogue, declare his sins, and ask for forgiveness for the scandal

15 "[G]rande crimen conforme nossa ley" SAA 334, 22 (Compendio de escamoth, 1728-1814), 265-267.

16 David de León's attempts to evade the parnassim, and his efforts to dodge an appearance before the body, does not seem to have been uncommon. De León's actions were quite similar to those taken by other accused adulterers within Portuguese Jewish communities. Take, for instance, Abraham Andrade and Sarah Pardo in Curaçao, and Moses Fernandes in Suriname, all of whom were accused of adultery in the latter quarter of the eighteenth century, and all of whom led the parnassim on a wild goose chase for weeks, if not months, before finally appearing to face their accusers. See Ben-Ur and Roitman, "Adultery Here and There."

17 See n. 4, above. SAA 334, inv. nr. 345 (Geboorteregister), 108, 112, 120. Only two children are mentioned as going to Suriname, and there are records of both Ester and Jeudit in Suriname. Ester Gomes Soares sent a letter from Amsterdam to the Portuguese Jewish Mahamad in Suriname in 1820 addressed to the administrators of orphans. NL-HaNA, Portugees-Israëlitische Gemeente Suriname, 1.05.11.18, inv. nr. 10, 16 January 1820. Jeudith de Sel. Gomes Soares was buried in Jodensavanne. NL-HaNA, Portugees-Israëlitische Gemeente Suriname, 1.05.11.18, inv. nr. 422, p. 2, number 8. 
that he had caused. This mantra was to be repeated three times in total. During the month of Elul, he was ordered to refrain from shaving, sit in a proscribed space in the synagogue, and visit the synagogue twice a week. Public acts of penance put penitents such as David de León before the community as a warning to others, while also providing a process by which the offender might be restored fully to the community. In addition, the public staging of penance was a way to regulate social behavior. Simha, however, due to her "great contrition for her crimes and submission to authority," had no penance to make whatsoever. Apparently, her confession to the parnassim and her evident remorse were enough to satisfy them. ${ }^{18}$

This case could indicate that while it was important for the man to perform a ritual of penance publically, women were not expected to carry out such a public act in the sacred space of the synagogue. It was certainly in contrast to general practice in early modern Christian society, where women were part of the culture of public penitence. For instance, in sixteenth- and seventeenth-century Germany women accused of adultery were often forced to wear distinctive clothing and do public penance in the church. Likewise, ecclesiastical authorities in early modern England often sentenced women to public displays of contrition. Women in British America were forced to stand in their local meetinghouse wearing white sheets and holding white wands, a traditional form of public penance for having sex outside marriage. ${ }^{19}$ Simha certainly had no money with which to pay a fine, which could have factored into the sentencing. ${ }^{20}$ However, de León was not fined either, and he was from a wealthier family. ${ }^{21}$

It may seem that Simha initially escaped the worst of the consequences for her "great crime against the law." However, in 1770, two years after the scandal

18 SAA 334 , inv. nr. 22, 267.

19 Joel F. Harrington, The Unwanted Child: The Fate of Foundlings, Orphans, and Juvenile Criminals in Early Modern Germany (Chicago: University of Chicago Press, 2009), 44; Bernard Capp, When Gossips Meet: Women, Family, and Neighbourhood in Early Modern England (Oxford: Oxford University Press, 2003), 101, 240, 247, 272, 298, 379. See also, Jim Sharpe, "Women, Witchcraft, and the Legal Process," in Women, Crime and the Courts in Early Modern England, ed. J.I. Kermode and Garthine Walker (Routledge: London, 1994), 119; Cynthia Lynn Lyerly, "Southern Colonial Protestant Women," in Encyclopedia of Women and Religion in North America, ed. Rosemary Skinner Keller and Rosemary Radford Ruether (Bloomington: Indiana University Press, 2006), 238.

20 She was already living quite precariously on the edges of poverty. SAA 334, inv. nr. 27 (Compendio de escamoth, 1767-1773), 127.

21 SAA 344, inv. nr. 285-287 (Register van administratie van de finta). This is an interesting contrast to the practice in Suriname and Curaçao, where fines seem to have been the norm. See Ben-Ur and Roitman, "Adultery Here and There." 
broke in Amsterdam, a Mr. de Vries arrived in Amsterdam on a ship from Suriname. He had in his possession a letter for the parnassim of the Portuguese Jewish community from Selomoh Gomes Soares. In this letter, Soares requested that they provide every possible assistance in transporting his daughters to him in Suriname. There is no record of any letter to Soares informing him of the events surrounding his wife's excommunication in the relatively complete books of letters sent by the Amsterdam community (uitgaande brieven), so it seems likely that he was notified of the scandal via informal means. ${ }^{22} \mathrm{He}$ asked that his daughters be sent with all possible speed to him so that they could be under his "paternal protection," a possible allusion to the moral unsuitability of his wife as a caretaker for their children, though there is evidence from other cases that fathers or the fathers' families were generally awarded custody. ${ }^{23}$

When the parnassim arrived on her doorstep with her husband's letter in hand, Simha was living on communal assistance and could not afford to feed the children. ${ }^{24}$ Her poverty left her in an extremely vulnerable position. Although she initially refused to relinquish her daughters to their father in Suriname, the parnassim visited several times over the coming weeks using "persuasive and suave" arguments—actually, threats—one of which included cutting off all community charity to her should she refuse. ${ }^{25}$ Simha was completely dependent upon the community's charity, as was her mother, who was mentally ill, her two daughters, and any child that may have been born of her adulterous affair with León. ${ }^{26}$ In the end, Simha acceded to the demands and allowed her daughters to be sent to their father in Suriname. ${ }^{27}$ Simha Salom

22 SAA 334, inv. nr. 1028BB (Documents concerning the Jewish communities in Amsterdam, Curaçao, Suriname, and Constantinople, 1750-1793); inv. nr. 95 (Copiador de cartas [Copies of outgoing letters], 1773-1784).

23 SAA 334, inv. nr. 94 (Copiador de cartas, 1764-1773), 332.

24 SAA 334, inv. nr. 27 (Compendio de escamoth, 1767-1773), 127.

25 "Argumentos suaveis e persuasivos." SAA 334, inv. nr. 27 (Compendio de escamoth, 17671773), 127, 145 .

26 On the mental illness of Simha's mother, see, SAA 334, inv. nr. 61 (Livro de segredos [Confidential book]), 31. Illegitimate children were registered in the community records, though usually with the notation mamzerta next to their names. A mamzer, a child of a forbidden union, is not considered a normative Jew and is permitted to marry only another mamzer or a convert to Judaism. Moreover, the stigma of the mamzer remains with the family indefinitely. See Rivka Haut, "The Agunah and Divorce," in Lifecycles: Jewish Women on Life Passages and Personal Milestones, ed. Debra Orenstein (Woodstock, VT: Jewish Lights Publishing, 1994), 1: 418, n. 4. We could find no record of any child born to Simha Salom or David de León in the birth registers, whether with the notation mamzerta or not. For an example, see SAA 345 (Geboorteregister), 118. The child could have died at birth or, for some other reason, not been registered. 
received a small legacy from her mother in 1787 , but by then, it was too late. ${ }^{28}$ Ester and Jeudit were in Suriname where it seems likely that they stayed for the rest of their lives. Jeudith de Sel. Gomes Soares was buried in Jodensavanne, the Jewish settlement in the interior of Suriname. ${ }^{29}$ It is doubtful that Simha ever saw her children again. ${ }^{30}$

Simha was not alone in her plight. For instance, Leah, the wife of Reuben, was accused of committing adultery with a non-Jewish neighbor or, even more shockingly, with her own brother, when her suspicious pregnancy was discovered in 1721. The couple lived in Nablus (Shechem), Eretz Israel, and Reuben had left her several days after their wedding, apparently to look for work, and not returned. ${ }^{31}$ In the meantime, Leah had gotten pregnant, and no one believed that Reuben could be the father. Simha and Leah's pregnancies, and others that were suspected of being the product of adulterous unions were, of course, scandalous events, and brought the infidelity of couples very publically to light. They were quite clearly the result of these women having been at least temporarily abandoned by their husbands. In fact, as Yosef Kaplan notes, all of the women he profiles in his study "Moral Panic in the Eighteenth-Century Sephardic Community of Amsterdam: The Threat of Eros" who were accused of adultery had been deserted by their spouses. ${ }^{32}$ The problem of the abandoned wife - the agunah, a woman "chained" or "anchored" to her husband because she is unable to divorce or remarry - has been around for millennia. However, the increased mobility of the early modern period, as well as the shifting social fabric of Jewish and non-Jewish communities, alike, also seems to have led to a growth in abandoned women, full stop. ${ }^{33}$

These were women like Simha, or the "bitter and unhappy" deserted wife in Jerusalem whose husband abandoned her three days after she bore him

28 SAA 334, inv. nr. 667 (Rachel Mendes da Costa, weduwe van Jacob Salom, 1757-1787) 1, 7 .

29 NL-HaNA, Portugees-Israëlitische Gemeente Suriname, 1.05.11.18, inv. nr. 422, p. 2, no. 8.

3o One Ester Gomes Soares sent a letter from Amsterdam to the Portuguese Mahamad in Suriname in 1820. It was addressed to the administrators of orphans. If it was Simha's daughter, she would have been fifty-seven at the time. NL-HaNA, Portugees-Israëlitische Gemeente Suriname, 1.05.11.18, inv. nr. 10, 16 January 1820.

Matt Goldish, Jewish Questions: Responsa on Sephardic Life in the Early Modern Period (Princeton, NJ: Princeton University Press, 2008), 136-38, "A Suspicious Pregnancy 1721, Case 37."

32 Kaplan, "Moral Panic in the Eighteenth-Century," 106.

33 Ibid., 111. 
a second daughter "and the woman and her two daughters were left naked and destitute, with no means of support [...] alone and forsaken [...] because there was nothing left to provide for her" according to the community leaders who wrote to see if the father could be found. ${ }^{34} \mathrm{~A}$ responsum written by the Sephardic scholar Moshe Aroquis of Salonika details the case of a Sephardic woman in the Ottoman Empire whose marital status was under consideration. Because of the controversy concerning her marital status, the young woman was considered an agunah. Aroquis was sympathetic to the woman's plight, describing her as an outcast among women, "destined by a rabbi's strict opinion to remain childless and single until her hair turns grey." ${ }^{35} \mathrm{He}$ was apparently referring to the correspondent of Ibn Habib, who had ruled that the young woman must receive a divorce $(\mathrm{get})$ in order to remarry. However, receiving a divorce was, and still is, not always a straightforward task for Jewish women.

In Jewish law, only the husband has the prerogative of executing and delivering a divorce, and there are essentially four reasons why a woman may be unable to obtain a Jewish get: the husband is mentally ill, thus legally incompetent to grant a divorce; a recalcitrant husband refuses to divorce his wife; the husband has died but there is no legally valid evidence of his death; or the husband abandons her and disappears. Of these reasons, the latter two came to the fore most often during the early modern period, and sometimes it was difficult to know if the woman had been intentionally abandoned, or if her husband had died and no word of his demise had reached her. ${ }^{36}$ The

34 Jerusalem, National and University Library, Ms. Jerusalem $8^{\circ} 61$, letter 171, cited in Ruth Lamdan, "Mothers and Children as Seen by Sixteenth-Century Rabbis in the Ottoman Empire," in Sephardic Family Life in the Early Modern Diaspora, ed.Julia Rebollo Lieberman (Waltham, MA: Brandeis University Press, 2011), 86.

35 Joseph R. Hacker, "The Sephardim in the Ottoman Empire in the Sixteenth Century," in Moreshet Sepharad: The Sephardic Legacy, ed. Haim Beinart (Jerusalem: Magnes Press, 1992), 2: 111, and his "Pride and Depression: Polarity and the Spiritual and Social Experience of the Iberian Exiles in the Ottoman Empire," in Culture and Society in Medieval Jewry: Studies Dedicated to the Memory of Haim Hillel Ben Sasson, ed. Menahem Ben Sasson, Robert Bonfil, and Joseph. R. Hacker (Jerusalem: Zalman Shazar Center, 1989) 570-72, cited in Hannah Davidson, "Communal Pride and Feminine Virtue: 'Suspecting Sivlonot' in the Jewish Communities of the Ottoman Empire in the Early Sixteenth Century," in Lieberman, Sephardic Family Life, 32.

$36 \quad$ One explanation for why the rabbis were so reluctant to declare a deserted husband dead even after years of absence and to grant the agunah permission to marry was the fear that, should the wife remarry and the former husband reappear, she would be an adulteress and any offspring of her new marriage would be mamzerim. In such cases, upon the first husband's return, the new husband must divorce the adulterous woman, who is then not permitted to remarry her first husband. Given the grave consequences of adulterous marriage, the rabbis were loath to verify a death without great certainty, even though, from 
Encyclopedia Judaica notes that, "the problem of the agunah is one of the most complex in halakhic discussions and is treated in great detail in halakhic literature." ${ }^{37}$ Moreover, the extensive concern with the ostensibly halakhically insoluble problem of the abandoned agunah highlights the serious repercussions of the gender and power differential operative at the very foundation of the Jewish legal system. The need for absolute certainty in declaring a man deceased placed an undue burden of proof on women, especially in cases of shipwreck or war, when finding an identifiable body was well-nigh impossible.

For instance, in the case of a man lost in a shipwreck, even though a survivor of the shipwreck testifies that he saw the husband drown, Jewish law does not consider him dead so long as the witness does not testify unequivocally that he saw him lying dead. ${ }^{38}$ Thus, when David Cunha declared to the members of the Mahamad on the 25th of December 1783 that his son-in-law, David Nunes Paiba had died in the warship on which he was serving, he must have been there himself. That, or the Amsterdam Mahamad may have been particularly lenient in accepting the testimony of such a clearly interested party. Cunha asked that the event be recorded "to serve as proof for the rabbinical court, as is necessary" so that his daughter could marry again. ${ }^{39}$

This need for certainty regarding the status of a man who had disappeared, coupled with the burden that abandoned women and children placed on the communities' charitable coffers, help explain why the records of the Amsterdam and London Sephardic communities in the latter part of the eighteenth century were filled with requests from, and bequests to, women who needed support to search for their missing husbands. To name just a few examples, in 1784, Rachel, wife of Daniel Casseres, asked the London community to travel to "Jamaica or places thereabouts where last he was known to have inhabited" to find her missing husband..$^{40}$ In June of 1783 , Leah, the daughter of Isaac Belmonte asked the Portuguese Jewish community of Amsterdam for funds. She hoped to follow her husband, Daniel Carodso, who had abandoned her. ${ }^{41}$ Esther Gabbai Isidro was granted a small sum to travel to Bordeaux, also in 1783 , to look for her missing spouse. ${ }^{42}$

the Talmudic period onward, rabbis counseled leniency in efforts to release an agunah. Goldstein, Enforced Marginality, 4.

37 http://www.jewishvirtuallibrary.org/agunah.

38 Menachem M. Brayer, The Jewish Woman in Rabbinic Literature: A Psychosocial Perspective, vol. 1 (Hoboken, NJ: KTAV, 1986), 16.

39 SAA 334, inv. nr. 29, 217. Cited in Kaplan, "Moral Panic in the Eighteenth-Century," 111.

40 London Metropolitan Archives, City of London, 4521/A/03/14/012.

41 SAA 344, inv. nr. 29, 242. Cited in Kaplan, "Moral Panic in the Eighteenth-Century,"11.

42 Ibid., fol. 252. 
It is beyond doubt that the early modern world, in general was a fluid one. This tendency toward mobility and movement was possibly even greater among the Jewish communities of Europe, particularly the Sephardim. This movement and mobility lead to a not inconsiderable group of women who were left to their own devices. Their poverty was an economic burden to their communities, while their situation as women alone led to gossip and, indeed, incidences of adultery and illegitimate children. We know that women like Leah in Nablus or Simha in Amsterdam were vulnerable. Their financial situation was often precarious, and their legal standing under Jewish law was often difficult, as they were condemned to stay married to a man who had deserted them and their children and were, therefore, unable to turn to another spouse for support. But what of men like Reuben and Selomoh?

\section{$3 \quad$ Feckless Fathers and Hopeless Husbands}

Solomon Maimon, the brilliant former Talmudist and rabbi, who eventually became a maskil in the circle of Moses Mendelssohn (in honor of whom he changed his last name), and, later still, a secular philosopher is, perhaps, best known for his autobiography (Lebensgeschichte), published in German around ${ }^{1792-93}{ }^{43}$ In this narrative, he admits that he abandoned his family, leaving his wife an agunah. In 1777, Maimon made the great "leap into the alien history" of eighteenth-century enlightened Germany. ${ }^{44}$ When he departed Poland for Germany, he was twenty-four years old, and left behind his family, which included his wife of thirteen years, a ten-year-old son named David, and several other children. He does not say how many, but mentions that his wedded life was "rather fruitful," and later speaks of David as the eldest son. ${ }^{45}$ There is no record of what he told his family when he departed for Königsberg. He only described his desire to leave the life of an early modern shtetl, full of poverty and tradition. He wrote: "Since my external circumstances continually grew worse because I no longer wanted to put up with my ordinary occupations and therefore found myself everywhere outside of my circle; also, on the other hand, I

43 Salomon Maimon's Lebensgeschichte. Von ihm selbst geschrieben und herausgegeben von K.P. Moritz (Berlin: Friedrich Vieweg, 1792-3). For the English translation, see Salomon Maimon, The Autobiography of Salomon Maimon with an Essay on Maimon's Philosophy, Introduction by Michael Shapiro, translated by J. Clark Murray (Urbana: University of Illinois Press, 2001).

44 Zvi Batscha, "Nachwort," in Salomon Maimons Lebensgeschichte: Von ihm selbst geschrieben, ed. Karl Philipp Moritz (Frankfurt am Main: Insel, 1984), 374-75.

45 Maimon, The Autobiography, 88. 
could not sufficiently satisfy my favorite inclination for scientific studies where I lived, I decided to go to Germany and there study medicine and, given this opportunity, also other sciences." 46

His wife disappeared from Maimon's Autobiography when he left for Germany. We do know that an envoy from his wife was sent to confront him in Germany to demand that he either return to Poland or divorce her. He, apparently, refused this request. After several more years in which she and the children lived in poverty in Poland, she and his eldest son traveled to Breslau, most likely with monies provided by the charitable funds of their community in Poland, to demand that he make a decision-divorce or return. Maimon finally concluded that "among the two evils here the lesser one was to be chosen, and I agreed to a divorce." ${ }^{47}$ Despite this decision, however, he continued to erect many obstacles to the divorce, including an unnecessary court proceeding at the beit din before finally acceding to grant a get. ${ }^{48}$

Maimon's references to his deserted wife account for but a few sentences in his entire life story. The almost complete exclusion of his wife from the pages of his biography minimize what she, as an agunah, suffered - poverty, inability to remarry, possibly social sanctions. Maimon's Autobiography allows us a first-hand glimpse of the forces driving the increase in abandoned wives in the early modern Jewish communities. Maimon wanted to travel, explore, the world, and make a new life for himself. In short, he wanted to "make a great leap" into all the possibilities offered by an "enlightened" Germany, including the chance to study secular subjects. This, he deemed, would only be possible if he left his wife and children. Thus, it is clear that it was not just poverty that drove men to abandon their families, but also a thirst for adventure, and a desire to live a different life, unencumbered by the expectations and traditions of the Jewish family.

This same desire may have played a part in Selomoh Gomes Soares's departure for Suriname. As was mentioned above, there is no record of him being desperately poor enough to have received charitable aid to travel or to be "dispatched" to the colonies. In any case, to the colonies he went, and there he established a new life-a life without Simha. The earliest known official record of Selomoh Gomes Soares's presence in Suriname is 1772. In that year, he received from Jacob de Abraham de Meza a piece of land valued at two hundred

\footnotetext{
46 Ibid., 93.

47 Ibid., 140.

48 Goldstein, Enforced Marginality, 36.
} 
Dutch guilders. ${ }^{49}$ However, we know Gomes Soares must have been there by at least 1770 because that is the year in which Mr. de Vries arrived in Amsterdam with his letter demanding his children be sent to him.

Ester and Jeudit must have arrived in Suriname by 1771 or 1772 . Soares's fortunes seem to have been on the rise by then. In 1774, some three or four years after his daughters would have arrived in Suriname, Soares sold to Samuel Cohen Nassy a house and plot of land in the province of the Jodensavanne, the Jewish agricultural settlement in the interior of the colony, between the land of Samuel Henriquez Fereyra and the said Nassy, for 1,500 Dutch guilders. ${ }^{50}$ In this same year, he served as witness to a mortgage contract between Portuguese Jews living in Paramaribo, the colony's capital. ${ }^{51}$ The scandal of his wife's adulterous behavior never seems to have affected Soares's reputation or career in Suriname. For instance, in 1777 , Selomoh Gomes Soares and David de Isaac Cohen Nassy formed a partnership and opened a pharmaceutical store to serve the infirm in the Jodensavanne, whether white or black, under the name Soares \& Company. ${ }^{52}$ At this same time, we know that Simha was still living off of communal charity in Amsterdam.

Despite this relative success, not everything seems to have gone completely smoothly for Gomes Soares. In 1785 , Soares along with three dozen other Portuguese Jewish heads of house (including two widows) were denied access to the synagogue because of their late taxes. Desirous of attending synagogue during Rosh Hashanah, he and the others worked out individual payment plans. Soares admitted he had trouble paying his annual taxes to the Portuguese Jewish community, and offered to pay half or some portion thereof. ${ }^{53}$ The fact that at least thirty-six other congregation members had trouble paying their synagogue dues is an indication that the community was not particularly wealthy. In any case, as was mentioned above, Soares served as a choir member in the jubilee celebration marking the one hundredth anniversary of Congregation Beraha VeSalom. ${ }^{54}$

49 NL-HaNA, Portugees-Israëlitische Gemeente Suriname, 1.05.11.18, inv. nr. 135, p. 67.

$50 \quad$ NL-HaNA, Portugees-Israëlitische Gemeente Suriname, 1.05.11.18, inv. nr. 135, pp. 68-69.

51 NL-HaNA, Portugees-Isrälitische Gemeente Suriname, 1.05.11.18, inv. nr. 787, 13 June 1774.

52 NL-HaNA, Suriname: Oud Notarieel Archief, 1699-1829, 1.05.11.14, inv. nr. 788, 23 February 1780; and 3 December 1777. In 1783, one David de la Parra, who claimed to be suffering from opthalmia veterana, was referred to them for his eye inflammation. The lack of doctors in the region was noted. NL-HaNA, Portugees-Israëlitische Gemeente Suriname, 1.05.11.18, inv. nr. 2, 17 October 1783 .

53 NL-HaNA, Portugees-Israëlitische Gemeente Suriname, 1.05.11.18, inv. nr. 2, 8 September 1785, p. 305 .

54 NL-HaNA, Portugees-Israëlitische Gemeente Suriname, 1.05.11.18, inv. nr. 2, 6 June 1787. 
And so his life in the Dutch colony of Suriname went, as far as can be garnered from the sources, with no concern for his wife back in Amsterdam. In 1789, he along with fourteen other Portuguese Jewish jehidim received the permission of the Mahamad to shave during the intermediary days of the High Holy Days. ${ }^{55} \mathrm{He}$ and seven others were granted the same dispensation for Passover of $1790 .{ }^{56}$ In 1795 , Soares was selected out of three applicants to be admitted as a doctor, surgeon, and apothecary of the poor with a salary of $55^{0}$ guilders. ${ }^{57}$ In 1796 , Soares treated two charity slaves (negros da sedaca), slaves responsible for the upkeep of the synagogue. ${ }^{58}$ Soares was still working in 1802, when he was identified as the pharmacist (boticario) charged with treating a widow's son stricken with a tropical parasitic disease (chagas). He apparently no longer served as a chirurajao, who would see the patient should his cure not work. ${ }^{59}$ On 30 July 1805 , Selomon Netanel Gomes Soares died in the Jodensavanne. ${ }^{60}$ He was buried on the following day, next to his business partner David Nassy (the former David de Isaac Cohen Nassy). ${ }^{61}$

There is no record of the Portuguese Jewish community of Amsterdam sending an envoy to Suriname to request that Gomes Soares return or divorce his wife. This could be because they were loath to have anyone return when they were already so actively trying to send poor and middling Jews away. Nevertheless, by this time, Gomes Soares was at least relatively prosperous, while Simha was living on communal charity, so it remains somewhat mysterious as to why no demands seem to have been placed on him to support his wife, especially considering the frequent communications between the Suriname and Amsterdam Jewish communities, both formal and informal. Nor is there any record that a divorce was either requested by Simha or the congregation,

55 NL-HaNA, Portugees-Israëlitische Gemeente Suriname, 1.05.11.18, inv. nr. 2, 11 October 1789 .

56 NL-HaNA, Portugees-Israëlitische Gemeente Suriname, 1.05.11.18, inv. nr. 2, 21 April 1790.

57 NL-HaNA, Portugees-Israëlitische Gemeente Suriname, 1.05.11.18, inv. nr. 3, 29 December 1795 .

58 NL-HaNA, Portugees-Israëlitische Gemeente Suriname, 1.05.11.18, inv. nr. 3, 27 December 1796.

59 NL-HaNA, Portugees-Israëlitische Gemeente Suriname, 1.05.11.18, inv. nr. 3, 2 May 1802.

6 o NL-HaNA, Portugees-Israëlitische Gemeente Suriname, 1.05.11.18, inv. nr. 418, died $4 \mathrm{Ab}$ 5565, p. 89; NL-HaNA, Portugees-Israëlitische Gemeente Suriname, 1.05.11.18, inv. nr. 423, buried 31 July 1805 (5 Ab 5565), p. 32.

61 NL-HaNA, Portugees-Israëlitische Gemeente Suriname, 1.05.11.18, inv. nr. 423, p. 33. NAN, NPIGS, inv. nr. 4, 5 August 1805. The applicant who sought to replace him, Abraham Moses Levy, requested to be admitted as dotour chirugiao and butecario of the Portuguese Jewish poor in Paramaribo. See NL-HaNA, Portugees-Israëlitische Gemeente Suriname, 1.05.11.18, inv. nr. 4, 5 August 1805 . Five days later, Levy was officially admitted to the post. 
and, as far as we can tell, they never divorced. In fact, in Simha's mother's will from 1787 , Simha is still listed as the "housewife of Selomoh Gomes Soares, currently in the West Indies." 62

What the cases of Maimon and Gomes Soares and their unfortunate families show us is how skewed the Jewish family and larger societal structures were in favor of men. The increasing mobility of the early modern period, the promises of the European Enlightenment and European expansion clearly provided heretofore unheard of options for men like Maimon and Gomes Soares were still limited in their access to all aspects of society, nevertheless readily availed themselves of the male prerogative to leave home and family and seek out opportunities they deemed intellectually, socially, and/or economically more promising. The wives, long confined within the traditional household and encumbered with responsibility for the welfare of their children, certainly could not easily undertake life in an unfamiliar modern (secular) environment. ${ }^{63}$

The adulterous affair of Simha Salom and David de León should be contextualized within the trend toward increasing mobility that characterized the early modern period and led to growing numbers of women and children being left behind, either temporarily or permanently. ${ }^{64}$ Historian Herman Roodenburg shows that twenty-four percent of all infidelity cases brought to the attention of the Amsterdam Dutch Reform consistory between 1578 and 1700 involved a wife whose husband was away in the East or West Indies. Of the women accused of infidelity during the period under study, eighty-three of their husbands had gone to the East Indies and four to the West Indies or Brazil. ${ }^{65}$ And it was not just within Amsterdam that such statistics applied. One hundred and one women were accused of either adultery or bigamy in Leiden between 1678 and 1794 , versus 132 men in the same time frame. Of course, it was easier to discover a woman's adultery if she became pregnant, especially if her husband was away, as was the case with Simha Salom or the unfortunate Rachel in

\footnotetext{
62 SAA 334, inv. nr. 667 (Rachel Mendes da Costa, weduwe van Jacob Salom, 1757-1787), 1.

63 Goldstein, Enforced Marginality, 156.

64 Leslie P. Moch, Moving Europeans: Migration in Western Europe since 1650 (Bloomington: Indiana University Press, 2003), 84-87; and Jan Lucassen, Dutch Long Distance Migration: A Concise History 1600-19oo (Amsterdam: IISG Research Paper 3, 1991), 20, 36.

65 Herman Roodenburg, Onder censuur: De kerkelijke tucht in de gereformeerde gemeente van Amsterdam, 1578-1700 (Hilversum: Verloren, 1990), 283.
} 
TABLE 22.1 Cases of Adultery, Protestant Reformed

Church, Amsterdam

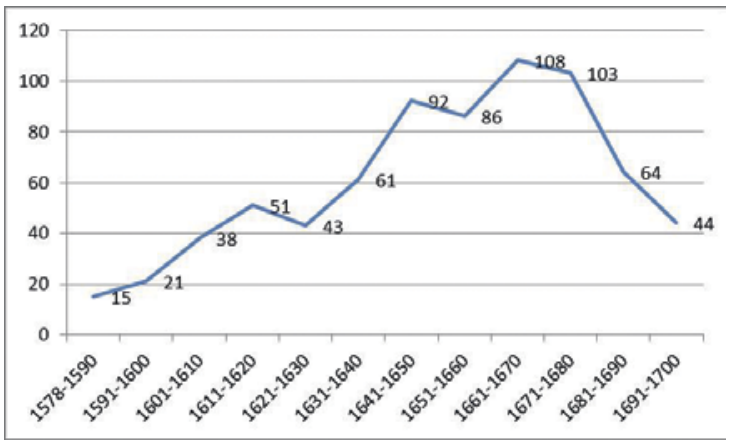

SOURCE: HERMAN ROODENBURG, ONDER CENSUUR,

P. 281

Nablus. ${ }^{66}$ This may account for the relatively high number of women accused of the crime.

In any case, many of the women accused of adultery or bigamy in Leiden stated that their husbands were in the East Indies. ${ }^{67}$ Although it is difficult to ascertain from the available sources, absent husbands could have, and, likely, did, play a role in the increase in cases of adultery that came before the "high court" Hof van Holland of the province of Holland in the latter half of the eighteenth century. A statistical profile of adultery as reflected in the aforementioned Hof van Holland inventory, for example, shows us that sixty-seven cases were recorded in the century and a half between 1597 to 1749 , while in the less than half a century from 1753 to 1800 , thirty-six cases were tried (Table 22.1). ${ }^{68}$

As the examples detailed above show, particularly the Salom/de León case, Jewish communities were not immune to this trend. In fact, some scholars speculate that it may have been more common within Jewish communities than in non-Jewish ones, due to the allegedly higher mobility of Jews during

66 This was also the situation in which Sarah Pardo found herself in Curaçao in 1775, when no one believed that her ailing husband could be the father of her unborn child, leading to a scandal within the already conflict-prone Portuguese Jewish community on the island. See Ben-Ur and Roitman, "Adultery Here and There," in Dutch Atlantic Connections, 208-16.

67 Else Margaretha Kloek, Wie hij zij, man of wijf. Vrouwengeschiedenis en de vroegmoderne tijd: Drie Leidse studies (Hilversum: Verloren, 1990), 142-45.

68 NL-HaNA, Hof van Holland, 3.03.01.01, inv. nr. 1.1. Roodenburg's analysis of adultery in Amsterdam's Dutch Reform church shows that adultery cases dramatically peaked during the two decades between 1661 and 1680. Herman Roodenburg, Onder censuur, 281. 
the early modern period. ${ }^{69}$ Until systematic research is undertaken comparing the two centuries beginning in the $1650 \mathrm{os}$ and $1750 \mathrm{os}$, it is impossible to say whether or not this statistical increase in the Christian society of the early modern Dutch Republic was actually mirrored within the Portuguese Jewish community. Two historians have indicated adultery was more common among Amsterdam's Portuguese Jews in the eighteenth than in the previous century. Yosef Kaplan, in an article that discusses about a dozen cases of marital infidelity, calls adultery among Amsterdam's Portuguese Jews in the eighteenth century an "extensive phenomenon" and traces its causality to ever-growing "tolerance towards sexuality in Western European societies" beginning in the $1670 s$ and "the satisfaction of erotic desires as a central goal in marriage." He also links the increase in mobility to this growth in adultery cases. ${ }^{70}$ Tirtsah Levie Bernfeld affirms Kaplan's findings, and remarks upon, "a growing neglect of morality among Dutch Sephardim [in the eighteenth century]."71 Historian Matt Goldish, who brought the case of Leah and Reuben to light, notes a rise in responsa and other documents related to adultery among Jews in Morocco, which "might suggest that infidelity and adultery were becoming more common" there among Jews from the mid-eighteenth century. ${ }^{72}$

Goldish's findings suggest that the rise in documented adultery cases was not, then, linked solely to social trends in Western Europe. Granted, this spike in reported incidents of adultery could reflect a growing preoccupation with shifts in the economic and social structure of the traditional Jewish family, including increased mobility and, consequently, more abandoned wives and children, rather than an actual increase in incidences of adultery itself. Herman Roodenburg, for example, cautions that his data does not say much about the behavior of the members of the church. Members from higher socio-economic positions, he surmises, had the wherewithal to keep their adultery from reaching the consistory, a fact well known among pastors of the congregation. Also, the rate of cases of prosecuted infidelity may have fluctuated over time as civil and ecclesiastical authorities' priorities shifted..$^{73}$ It is likely that marital infidelity was common in any age, as one historian of the eighteenth-century Cape

\footnotetext{
69 Kaplan, "Moral Panic in the Eighteenth Century," 112.

70 Ibid. Kaplan points out that poverty from the 1730 and increasing mobility intensified the phenomenon.

71 Tirtsah Levie Bernfeld, "Sephardic Women in Holland's Golden Age," in Lieberman, Sephardic Family Life, 182.

72 Goldish, Jewish Questions, $136-38$.

73 Roodenburg, Onder censuur, 281.
} 
Colony in contemporary South Africa also argues, and as a number of scholars writing in broader contexts have long posited. ${ }^{74}$

But what is "common" for early modernity can only be quantified in comparison to other contemporaneous transgressions regarded (at least in theory) as equally serious. If adultery was both common and a central concern, this concern may possibly be linked to several factors. It could be due to the fact that "marriage and sex had become public anxieties in Europe during the Protestant and Catholic Reformations" and that mainstream churches during this period set up special institutions specifically geared toward regulating and punishing transgressive sexual behavior. ${ }^{75}$ The split of the Roman Catholic Church created not only the Protestant community, but also communal barriers in need of policing. The reaction of Portuguese Jewish authorities to marital infidelity differed over time qualitatively, just as it seems did those of Christian religious leaders. A major preoccupation of the eighteenth-century Portuguese Jewish community in Amsterdam was heterosexual wrongdoing, particularly adultery and clandestine marriages. ${ }^{76}$ As Kaplan describes, heightened scrutiny and verbosity characterizes trial proceedings from the mid-eighteenth century, and gone were the oblique euphemisms and lenient punishments of the previous century. This "moral panic" (the spike in adultery cases beginning in the second half of the eighteen century) in both Jewish and Christian communities seem to at least be partially tied to the increased mobility of the early modern period, with the concomitant increase in spousal desertion, bigamy, and illegitimacy.

74 George Peter Murdock, Social Structure (New York: The Free Press, 1949), 26o; Murder and adultery were "common enough crimes in any age." Nigel Penn, "The Wife, the Farmer and the Farmer's Slaves: Adultery and Murder on a Frontier Society in the Early Eighteenth Century Cape," Kronos 28 (November 2002): 1-20, 1; James A. Brundage, "Adultery and Fornication: A Study in Legal Theology," in Sexual Practices and the Medieval Church, ed. V.L. Bullough and J.A. Brundage (Buffalo: Prometheus, 1982), 133-34; W.E.H. Lecky, History of European Morals, 2 vols. (New York: George Braziller, 1955), 2: 282; Bronislaw Malinowski, "Parenthood, The Basis of Social Structure," in The Family: Its Structure and Function, ed. Rose Laub Cross (New York: St. Martin's Press, 1964), 18-19.

75 Steven Ozment, When Father Ruled: Family Life in Reformation Europe (Cambridge, MA: Harvard University Press, 1983).

$7^{6}$ Yosef Kaplan, "Deviance and Excommunication in the Eighteenth Century: A Chapter in the Social History of the Sephardic community of Amsterdam," in Dutch Jewish History Dutch Jewish History, Vol. 3: Proceedings of the Fifth Symposium on the History of the Jews in the Netherlands, ed. J. Michman (Jerusalem and Assen: Hebrew University and Van Gorcum, 1993), 103. 
The sad case of Simha Salom and her absconding husband, Selomoh Gomes Soares, serves as a vivid illustration of the shifts taking place within the Portuguese Jewish community in the early modern period. Increased mobility and migration, most clearly seen in the European expansion overseas, but also shown in increased intra-European movement, and the Enlightenment and haskalah, with their associated possibilities for life outside the confines of Jewish communities, had no small effect on Jewish families, Ashkenazim and Sephardim alike. ${ }^{77}$ One of these seems to have been an increase in the number of abandoned women and children. Clearly, in the case of Simha Salom and her husband Selomoh Gomes Soares, the broad stretch of the Atlantic world as traversed by the highly mobile Jewish community exacerbated the hardships endured for family members left behind. But this was a trend mirrored in Christian society, as well, a fact the startling statistics of the number of adultery and bigamy cases linked to a spouse in the Dutch East and West Indies shows.

The early modern emphasis on the strong family and the strict implementation of marriage and divorce laws as mechanisms to enforce Jewish communities cohesiveness in a sometimes threatening diasporic situation continued well into the twentieth century. ${ }^{78}$ The traditional Jewish community, enclosed within the dominant society, established its own internal governance with a modicum of autonomy that included rabbinical courts, its own legal system for family law and contracts, and structures of social and political hierarchy. Gender inequality, with Jewish men in control, and with women, because of their legally sanctioned subaltern status, marginalized and largely confined to the domestic sphere, was at the heart of this governance system. Agunot, especially deserted wives, were burdened by an even more oppressive enforced marginality: their systemic exclusion from perhaps the only domain where a woman had value in her traditional community—as wife of a household. ${ }^{79}$

The differential of power and privilege between men and women is obvious in cases like that of Leah in Morocco, the "bitter" agunah in Jerusalem, the young Sephardic woman in the Ottoman Empire, or Maimon's unnamed wife. They were all trapped, unable to free themselves of their marriages, suffering societal sanctions as a woman with little or no status because of an absent

77 Moses A. Shulvass, From East to West: The Westward Migration of Jews from Eastern Europe During the Seventeenth and Eighteenth Centuries (Detroit: Wayne State University Press, 1971).

78 Goldstein, Enforced Marginality, 154.

79 This paragraph is paraphrased from ibid., 153 . 
husband, and with minimal resources to support themselves. The kind of impoverishment of women and children that so commonly resulted from spousal abandonment only served to further aggravate the gendered power differential in the early modern period. In the case of Simha Salom, her husband's financial abandonment of her left her entirely at the mercy of the parnassim who controlled access to communal charitable funds. This, in turn, left her little recourse when these communal authorities demanded that her children be turned over to their father. This highlights the male-dominated system of the Portuguese Jewish communities, which privileged a father's authority above a mother's, and left women with very little room in which to maneuver in asserting their rights to their children. This same community routinely sent children to live with their father or his family in case of divorce, and considered illegitimate daughters of Portuguese fathers and Christian mothers eligible for the Dotar dowry, but not the other way around.

The early modern period was a time of serious shifts culturally, economically, and socially. The Jewish communities of Europe were not immune from these shifts. In fact, Portuguese Jews, due to their familial and trade networks, coupled with political circumstances, pushed them to the forefront of economic change. ${ }^{80}$ Yet there were also social and cultural changes afoot. These very networks and this mobility which helped foster the global trade in which they were disproportionately present, also helped spur an intensified movement, mostly of men. This, in turn, meant that the (Portuguese) Jewish family was tested as never before. Rates of (prosecuted) adultery rose, as did problems with unauthorized marriages, and illegitimate children in the eighteenth century. Part and parcel of these strains were deserted women and their children. All of which does, indeed, call into question the compelling myth of the Jewish family as fundamentally strong, stable, warm, and supportive. No doubt some were, but many families also buckled under the stress of societal and economic dislocations, as the various cases in this chapter show.

\section{Bibliography}

Amsterdam Municipal Archives (SAA), Portugees-Israëlietische Gemeente, 334.

Batscha, Zvi. "Nachwort." In Salomon Maimons Lebensgeschichte: Von ihm selbst geschrieben. Edited by Karl Philipp Moritz, 329-92. Frankfurt am Main: Insel, 1984.

$80 \quad$ Jessica V. Roitman, The Same But Different? Inter-cultural Trade and the Sephardim, 15951640 (Leiden: Brill, 2011). 
Beinart, Haim, ed. Moreshet Sepharad: The Sephardic Legacy. 2 vols. Jerusalem: Magnes Press, 1992.

Ben Sasson, M., R. Bonfil, and J.R. Hacker, eds. Culture and Society in Medieval Jewry: Studies Dedicated to the Memory of Haim Hillel Ben Sasson. [Hebrew] Jerusalem: Zalman Shazar Center, 1989.

Ben-Ur, Aviva, and Jessica Vance Roitman. "Adultery Here and There: Crossing Sexual Boundaries in the Dutch Jewish Atlantic." In Dutch Atlantic Connections, 1680-180o: Linking Empires, Bridging Borders. Edited by Gert Oostindie and Jessica Vance Roitman, 185-223. Leiden: Brill, 2014.

Brayer, Menachem M. The Jewish Woman in Rabbinic Literature: A Psychosocial Perspective. Vol. 1. Hoboken, NJ: KTAV, 1986.

Brundage, James A. "Adultery and Fornication: A Study in Legal Theology." In Sexual Practices and the Medieval Church. Edited by V.L. Bullough and J.A. Brundage, 12934. Buffalo: Prometheus, 1982.

Bullough, V.L., and J.A. Brundage, eds. Sexual Practices and the Medieval Church. Buffalo: Prometheus, 1982.

Capp, Bernard. When Gossips Meet: Women, Family, and Neighbourhood in Early Modern England. Oxford: Oxford University Press, 2003.

Cohen, Robert. Jews in Another Environment. Surinam in the Second Half of the Eighteenth Century. Leiden: Brill, 1991.

Cohen, Steven M., and Paula E. Hyman, eds. The Jewish Family: Myths and Reality. New York: Holmes and Meier, 1986.

Cross, Rose Laub. The Family: Its Structure and Function. New York: St. Martin's Press, 1964.

Davidson, Hannah. "Communal Pride and Feminine Virtue: 'Suspecting Sivlonot' in the Jewish Communities of the Ottoman Empire in the Early Sixteenth Century." In Sephardic Family Life in the Early Modern Diaspora. Edited by Julia Rebollo Lieberman, 23-69. Waltham, MA: Brandeis University Press, 2011.

Goldish, Matt. Jewish Questions: Responsa on Sephardic Life in the Early Modern Period. Princeton, NJ: Princeton University Press, 2008.

Goldstein, Bluma. Enforced Marginality: Jewish Narratives on Abandoned Wives. Berkeley: University of California Press, 2007.

Hacker, Joseph. "Pride and Depression: Polarity and the Spiritual and Social Experience of the Iberian Exiles in the Ottoman Empire." [Hebrew] In Culture and Society in Medieval Jewry: Studies Dedicated to the Memory of Haim Hillel Ben Sasson. Edited by M. Ben Sasson, R. Bonfil, and J.R. Hacker, 541-86. Jerusalem: The Shazar Center, 1989 .

Hacker, Joseph. "The Sephardim in the Ottoman Empire in the Sixteenth Century." In Moreshet Sepharad: The Sephardic Legacy. 2 Vols. Edited by Haim Beinart, 1: 109-33. Jerusalem: Magnes Press, 1992. 
Harrington, Joel F. The Unwanted Child: The Fate of Foundlings, Orphans, and Juvenile Criminals in Early Modern Germany. Chicago: University of Chicago Press, 2009.

Haut, Rivka. "The Agunah and Divorce." In Lifecycles:Jewish Women on Life Passages and Personal Milestones. 2 Vols. Edited by Debra Orenstein, 1: 188-200. Woodstock, VT: Jewish Lights Publishing, 1994.

Hyman, Paula E. "Introduction: Perspectives on the Evolving Jewish Family." In The Jewish Family: Myths and Reality. Edited by Steven M. Cohen and Paula E. Hyman, 3-13. New York: Holmes and Meier, 1986.

Israel, Jonathan I., and Reinier Salverda, eds. Dutch Jewry. Its History and Secular Culture (1500-200o). Leiden: Brill, 2002.

Kaplan, Yosef. "Deviance and Excommunication in the Eighteenth Century: A Chapter in the Social History of the Sephardic community of Amsterdam." In Dutch Jewish History. Vol. 3: Proceedings of the Fifth Symposium on the History of the Jews in the Netherlands. Edited by J. Michman, 103-15. Jerusalem and Assen: Hebrew University and Van Gorcum, 1993.

Kaplan, Yosef. "Moral Panic in the 18th-Century Sephardic Community of Amsterdam: The Threat of Eros." In Dutch Jewry. Its History and Secular Culture (1500-2000). Edited by Jonathan Israel and Reinier Salverda, 103-23. Leiden: Brill, 2002.

Keller, Rosemary Skinner, and Rosemary Radford Ruether, eds. Encyclopedia of Women and Religion in North America. Bloomington: Indiana University Press, 2006.

Kermode, J.I., and Garthine Walker, eds. Women, Crime and the Courts in Early Modern England. Routledge: London, 1994.

Kloek, Else Margareth. Wie hij zij, man of wijf. Vrouwengeschiedenis en de vroegmoderne tijd: Drie Leidse studies. Hilversum: Verloren, 1990.

Lamdan, Ruth. "Mothers and Children as Seen by Sixteenth-Century Rabbis in the Ottoman Empire." In Sephardic Family Life in the Early Modern Diaspora. Edited by Julia Rebollo Lieberman, 70-100. Waltham, MA: Brandeis University Press, 2011.

Lecky, W.E.H. History of European Morals. 2 vols. New York: George Braziller, 1955.

Levie Bernfeld, Tirtsah. "Financing Poor Relief in the Spanish-Portuguese Jewish Community in Amsterdam in the Seventeenth and Eighteenth Centuries." In Dutch Jewry. Its History and Secular Culture (1500-200o). Edited by Jonathan Israel and Reinier Salverda, 63-102. Leiden: Brill, 2002.

Levie Bernfeld, Tirtsah. Poverty and Welfare Among the Portuguese Jews in Early Modern Amsterdam. Liverpool: Littman Library of Jewish Civilization and Liverpool University Press, 2012.

Lieberman, Julia Rebollo, ed. Sephardic Family Life in the Early Modern Diaspora. Waltham, MA: Brandeis University Press, 2011.

London Metropolitan Archives, City of London, Spanish and Jews' Congregation, 4521. Lucassen, Jan. Dutch Long Distance Migration: A Concise History 16oo-19oo. Amsterdam: IIS G Research Paper 3, 1991. 
Lyerly, Cynthia Lynn. "Southern Colonial Protestant Women." In Encyclopedia of Women and Religion in North America. Edited by Rosemary Skinner Keller and Rosemary Radford Ruether, 236-41. Bloomington: Indiana University Press, 2006.

Maimon, Salomon. The Autobiography of Salomon Maimon with an Essay on Maimon's Philosophy. Introduction by Michael Shapiro. Translated by J. Clark Murray. Urbana: University of Illinois Press, 2001.

Maimon, Salomon. Lebensgeschichte. Von ihm selbst geschrieben und herausgegeben von K. P. Moritz. Berlin: Friedrich Vieweg, 1792-3.

Malinowski, Bronislaw. "Parenthood, The Basis of Social Structure." In The Family: Its Structure and Function. Edited by Rose Laub Cross, 3-19. New York: St. Martin's Press, 1964.

Moch, Leslie P. Moving Europeans: Migration in Western Europe since 1650. Bloomington: Indiana University Press, 2003.

Murdock, George Peter. Social Structure. New York: The Free Press, 1949.

National and University Library, Jerusalem. Ms. Jerusalem $8^{\circ} 61$.

National Archive of the Netherlands, The Hague (NL-HaNA)

Hof van Holland, 3.03.01.01

Suriname: Nederlands Portugees-Israëlitische Gemeente (Portugees-Israëlitische Gemeente Suriname), 1.05.11.18

Suriname: Oud Notarieel Archief, 1699-1829, 1.05.11.14.

Nusteling, Hubert Ph. H. "The Jews in the Republic of the United Provinces: Origin, Numbers and Dispersion." In Dutch Jewry. Its History and Secular Culture (1500200o). Edited by Jonathan Israel and Reinier Salverda, 43-62. Leiden: Brill, 2002.

Orenstein, Debra, ed. Lifecycles:Jewish Women on Life Passages and Personal Milestones. Woodstock, VT: Jewish Lights Publishing, 1994.

Ozment, Steven. When Fathers Ruled: Family Life in Reformation Europe. Cambridge, MA: Harvard University Press, 1983.

Penn, Nigel. “The Wife, the Farmer and the Farmer's Slaves: Adultery and Murder on a Frontier Society in the Early Eighteenth Century Cape." Kronos 28 (2002): 1-20.

Pinto, Isaac de. Reflexoens Politicas, Tocante à Constituiçám da Naçam Judaica, Exposiçam do estado de suas Finanças, causas dos atrasos, e desordens que se experimentam, e meyos de os prevenir. Amsterdam, 1748.

Roitman, Jessica Vance. "The Repercussions of Rumor: An Adultery Case from 18th Century Curaçao." In A Sefardic Pepper-Pot in the Caribbean. Edited by Michael Studemund-Halévy, 124-35. Barcelona: Tirocinio, 2016.

Roitman, Jessica Vance. The Same But Different? Inter-cultural Trade and the Sephardim, 1595-1640. Leiden: Brill, 2011.

Roodenburg, Herman. Onder censuur: De kerkelijke tucht in de gereformeerde gemeente van Amsterdam, 1578-170o. Hilversum: Verloren, 1990. 
Sharpe, Jim. "Women, Witchcraft, and the Legal Process." In Women, Crime and The Courts in Early Modern England. Edited by J.I. Kermode and Garthine Walker, 10624. Routledge: London, 1994.

Shulvass, Moses A. From East to West: The Westward Migration of Jews from Eastern Europe During the Seventeenth and Eighteenth Centuries. Detroit: Wayne State University Press, 1971.

Studemund-Halévy, Michael, ed. A Sefardic Pepper-Pot in the Caribbean. Barcelona: Tirocinio, 2016.

Waldman, Morris D. "Family Desertion." In Proceedings of the Sixth Biennial Session of the National Conference of Jewish Charities in the United States (St. Louis, May 17-19, 1910), 54-111. Baltimore: Kohn and Pollock, 1910. 